\title{
REVISED The performance of bovine serum albumin filtration by using polyethersulfone-Tetronic 304 blend Ultrafiltration
}

\section{Membrane [version 2; peer review: 2 approved]}

\author{
Fachrul Razi ${ }^{1}$, Sri Mulyati1,2, Nasrul Arahman (iD1,2 \\ ${ }^{1}$ Chemical Engineering Department, Universitas Syiah Kuala, Banda Aceh, Aceh, 23211, Indonesia \\ ${ }^{2}$ Graduate School of Environmental Management, Universitas Syiah Kuala, Banda Aceh, Indonesia
}

\author{
V2 First published: 24 Jun 2019, 8:953 \\ https://doi.org/10.12688/f1000research.18740.1 \\ Latest published: 07 Nov 2019, 8:953 \\ https://doi.org/10.12688/f1000research.18740.2
}

\section{Abstract}

Background: Membrane technology has been widely applied for protein purification. In applications for protein separation, a membrane with stable filtration performance is necessary. In this work, two types of hollow fiber membranes with different characteristic were used to study the filtration profile of bovine serum albumin.

Methods: A single piece of hollow fiber module was used for ultrafiltration testing using UF0 and UFT304 membranes. Flux and rejection of BSA solution were collected based on a pressure-driven inside filtration model.

Results: Ultrafiltration experiments showed that the flux of UFT304 membrane was higher than that of UF0 membrane in all applied pressure condition. Solute rejection reaches 90 and $88 \%$ for ultrafiltration of BSA solution on the operating pressure of $0.5 \mathrm{~atm}$ using UFO and UFT304 membranes, respectively.

Conclusion: In general, UFT304 membranes has better ultrafiltration performance for BSA separation than UF0 membranes. The UFT304 membrane has a more stable flux for up to two hours of filtration.

Keywords

albumin, solute rejection, polyethersulfone, ultrafiltration

\begin{tabular}{|c|c|c|}
\hline \multicolumn{3}{|c|}{ Open Peer Review } \\
\hline \multicolumn{3}{|c|}{ Approval Status $\checkmark$} \\
\hline & 1 & 2 \\
\hline \multicolumn{3}{|l|}{ version 2} \\
\hline (revision) & $\checkmark$ & $\begin{array}{l} \\
\text { view }\end{array}$ \\
\hline 07 Nov 2019 & a & s \\
\hline version 1 & $?$ & $?$ \\
\hline 24 Jun 2019 & view & view \\
\hline
\end{tabular}

1. Lisendra Marbelia, Gadjah Mada University, Yogyakarta, Indonesia

2. Alagumalai Nagendran AD, Alagappa Government Arts College, Karaikudi, India Any reports and responses or comments on the article can be found at the end of the article.

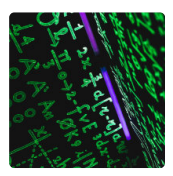

This article is included in the Mathematical, Physical, and Computational Sciences

collection. 
Corresponding author: Nasrul Arahman (nasrular@unsyiah.ac.id)

Author roles: Razi F: Writing - Original Draft Preparation; Mulyati S: Writing - Original Draft Preparation; Arahman N:

Conceptualization, Formal Analysis, Investigation, Methodology

Competing interests: No competing interests were disclosed.

Grant information: The author(s) declared that no grants were involved in supporting this work.

Copyright: ( 2019 Razi F et al. This is an open access article distributed under the terms of the Creative Commons Attribution License, which permits unrestricted use, distribution, and reproduction in any medium, provided the original work is properly cited.

How to cite this article: Razi $F$, Mulyati $S$ and Arahman N. The performance of bovine serum albumin filtration by using polyethersulfone-Tetronic 304 blend Ultrafiltration Membrane [version 2; peer review: $\mathbf{2}$ approved] F1000Research 2019, 8:953 https://doi.org/10.12688/f1000research.18740.2

First published: 24 Jun 2019, 8:953 https://doi.org/10.12688/f1000research.18740.1 


\section{REVISED Amendments from Version 1}

We changed the sentence in Results part of abstract from "solute rejection was achieved up to $90 \%$ for ultrafiltration of BSA solution by using UFO membrane obtained on the operating pressure of $0.5 \mathrm{~atm}$ " became "Solute rejection reaches 90 and $88 \%$ for ultrafiltration of BSA solution on the operating pressure of $0.5 \mathrm{~atm}$ using UF0 and UFT304 membranes, respectively"

We putted a reference in last paragraph of introduction about the Tetronic modified PES membranes. Putting this reference did not make change the number order other reference, because the reference have been cited in previous part.

We have added more information about filtration technique in "Methods" part

We have revised the graphs in Figure 2a, 2b, and Figure 3 by adding error bar data

Any further responses from the reviewers can be found at the end of the article

\section{Introduction}

Albumin proteins are one of the most important substances in the human body. Albumin maintains the balance of vascular fluid, forms new cell tissue, and functions acts as an antibody ${ }^{1}$. Albumin can help to reduce the risk of stroke and coronary heart disease ${ }^{2}$. Continuous experimentation is performed to establish the best method for isolation of protein from egg white to get the best quality albumin. The most popular technique is precipitation with $\mathrm{Na}_{2} \mathrm{SO}_{4}$ or (NH4) $\mathrm{SO}_{4}$ at $25^{\circ} \mathrm{C}$ and $\mathrm{pH} 4-7$. The protein-purifying method used in the precipitation technique can result in a large albumin yield, but the protein product contains the residue of precipitate materials, namely ammonium sulfate or sodium sulfate, which can potentially harmful ${ }^{3}$. The low purity and loss of albumin during the purification process has led researchers to search for alternative methods to address these short-comings.

Rapid development in the field of biotechnology has allowed for the separation of proteins with safer and more efficient methods, namely purification using membrane technology (ultrafiltration, UF). This method has been reported to successfully achieve protein fractionation through UF with several advantages compared with the conventional separation using biology/ chemistry methods $\mathrm{s}^{4-6}$. The main advantage being generating a product with high purity level and low toxicity ${ }^{7}$.

Despite these advantages, ultrafiltration technology also has some drawbacks. In many cases, protein molecules are easily absorbed on to the surface of hydrophobic membranes, such as polyethersulfone (PES), resulting in fouling. As a consequence, membrane flux decreases drastically along with the operation time. Modification of membrane surface traits is one solution to minimize the fouling of the membrane surface ${ }^{8,9}$.

In this research, the performance of two type hollow fiber membranes for BSA separation was investigated, one made of PES/ N-Methyl-2-pyrrolidone (NMP) and PES/NMP/Tetronic 304 system. Tetronic 304 is a non-ionic surfactant with two bonds of polyethylene oxide (PEO) and two bonds of polypropylene oxide (PPO) to ethylene diamine group. This surfactant potentially improves hydrophilic traits of the PES membrane due to its PEO group. This study aimed to investigate and establish the profile of BSA solution filtration using a standard PES membrane and a membrane modified with Tetronic 304 surfactant for permeability and rejection parameters.

\section{Methods}

We used two types of hollow fibre membrane made of polyethersulfone (PES, E6020P: BASF Co. Ludwigshafen, Germany; FN. 218189-009)/N-Methylpyrrolidone (Merck Germany, 606-021-00-7) (labeled as UF0), and PES/NMP/Tetronic 304 (BASF, Germany) system (labeled as UFT304). UF0 membrane has inner and outer diameters of 699 and $776 \mu \mathrm{m}$, respectively. UFT304 membrane has an inner diameter of $705 \mu \mathrm{m}$ and the outer diameter of $796 \mu \mathrm{m}$. The hydrophilicity characteristics based on water contact angle data are $74.0^{\circ}$ and $62.0^{\circ}$ for UF0 and UFT304 membrane, respectively. Protein model was bovine serum albumin (BSA) Cohn fraction V, pH 7 (WAKO Pure Chemical Industries, Japan; 017-23294).

\section{Characterization of hollow fibre membrane}

Membrane characterization was performed to establish the morphology of all membrane types using scanning electron microscopy (SEM, Hitachi Co, S-800, Japan) with voltage acceleration at $20 \mathrm{kV}$, with a convergence angle of $-30^{\circ}$, beam current x. $6.09 \mathrm{~mm}$; y.5.79 mm, and diameter of the beam of $0.006 \mathrm{~nm}$. Before the scanning electron microscopy (SEM) test, the membrane was soaked in liquid nitrogen for around five minutes, after the membrane turned rigid. This treatment was performed to prevent any change in the membrane structure when placing the sample on the SEM plate. The membrane was dried in freeze-drier overnight. One piece of the membrane was taken randomly and mounted on the sampling tubs (Hitachi, 10-004139-1, stubs $\varnothing 25 \times 16 \mathrm{~mm} \times \mathrm{M} 4,2 \times 90^{\circ}$ ) wrapped with carbon tape, and then coated with osmium coater (Neoc-STB, Meiwafosis Co., Ltd., Japan) sputtering. The sample was placed on the SEM panel for the picture-capturing process at 100 and 3000 magnification for whole and enlarged cross-section, respectively. Captured images were processed using Irfan View v.3.45

\section{The designing of ultrafiltration module}

The ultrafiltration module was designed using a single membrane module as previously described ${ }^{10}$. Ultrafiltration module consisted of a peristaltic pump (Watson Marlow, SciQ 323), a circuit of hose for feed flow, two pressure gauges (WIKA 213.53), valve, and hollow fibre membrane installed in the circuit. It was also equipped with feed, permeate, and retentate container.

\section{Pure water, and albumin solution-separating process}

The filtration of pure water and BSA solution was conducted by flowing the feed solution to the membrane using a peristaltic pump (Watson Marlow, SciQ 323). For pure water flux measurements, filtration was carried out at an operating pressure of $0.3 ; 0.5 ; 1.0$; and $1.5 \mathrm{~atm}$. Three pieces of the membrane were tested at every operating pressure by repeating three times. The permeate was collected every 10-minute filtration, and its 
weight was measured by an auto digital balance (Shimadzu, Japan; ATY224). The received data of permeate weight were then converted in a volume unit. The average of flux at each operating pressure is obtained from 9 times the filtration process. BSA solution filtration process were carried out for 120 minutes at a constant operating pressure of $0.5 \mathrm{~atm}$. BSA solution was made at a concentration of $500 \mathrm{ppm}$ at constant $\mathrm{pH}$ of 4.5. The permeate volume of BSA filtration was also collected every 10 minutes. The average permeability data were obtained from 3 measurements of each membrane.

Pure water flux and permeability of albumin solution were measured with Equation 1) and Equation 2) ${ }^{11}$. The filtration process is carried out at several operating pressures, which are 0,$5 ; 1.00$; and $1.5 \mathrm{Atm}$.

Flux $=\frac{\mathrm{V}}{\text { A.t }}$

Permeability $=\frac{\mathrm{V}}{\text { A.t.P }}$

$\mathrm{V}$ is a permeate volume, $\mathrm{A}$ is the membrane surface area, $\mathrm{t}$ is filtration time, and $\mathrm{P}$ is operational pressure. BSA concentration in permeate and retentate was then analyzed using a spectrophotometer. Rejection capability of the membrane can be determined using the equations as follows ${ }^{11}$ :

Rejection $=\frac{\mathrm{C}_{\mathrm{F}}-\mathrm{C}_{\mathrm{p}}}{\mathrm{C}_{\mathrm{F}}} \times 100 \%$
$\mathrm{C}_{\mathrm{F}}$ and $\mathrm{Cp}$ are protein concentration in sample and permeate analyzed by a spectrophotometer UV-Vis (Shimadzu UV-1800) at a wavelength of 278.0.

\section{Result}

\section{Membrane structure}

SEM images of the two membrane are shown in Figure 1 (see underlying data ${ }^{12}$ ). The morphological structure of membrane of the inner and outer surface were recorded with SEM at 3000x magnification as shown in Figure 1b and Figure 1c. Differences in pore structure and macrovoid pattern are clearly visible. The UFT304 membrane had larger pores with greater quantity of longer macrovoids. This likely effected ultrafiltration process of BSA protein as discussed below. Figure $1 \mathrm{~b}$ and Figure 1c also shows a large sponge structure in the middle of UF0 membrane which is absent in the UFT304 membrane. The increase in number and size of macrovoid was caused by the addition of polymeric surfactant. During the solidification process of the membrane in the coagulation batch, part of the additive leached out of the polymer system. Therefore, a large macrovoid structure was formed.

\section{Flux and rejection of BSA}

One important parameter for the membrane performance is its capability to filter solutions, referred to as flux or permeability. Another important parameter is the capability of membrane to remove components or particles from the solution, commonly known as solute rejection. In this study the ultrafiltration capability of the membrane was tested using a single membrane of hollow fibre (single module) designed with pressure driven
UF0

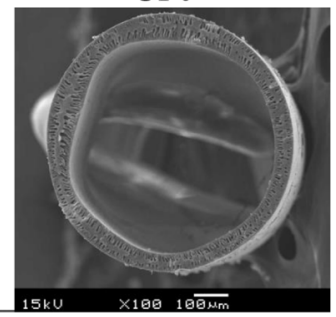

UFT304

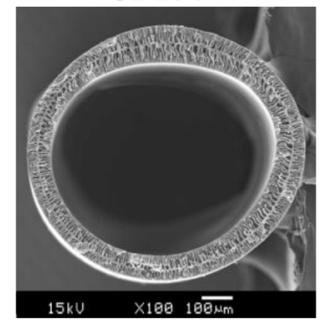

a). Whole cross-section
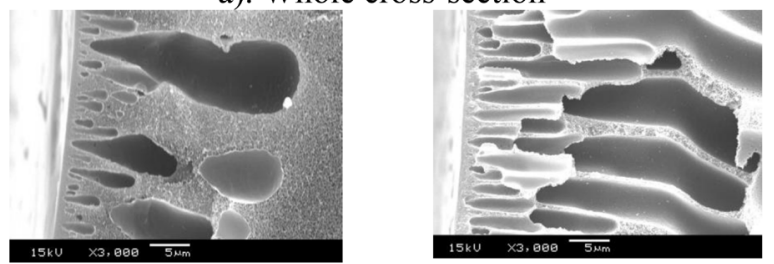

b). Inner section

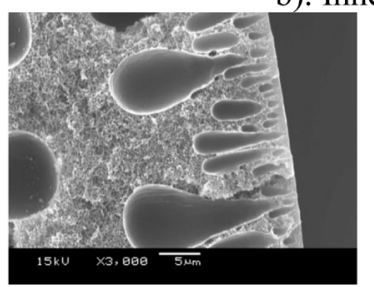

c). Outer section

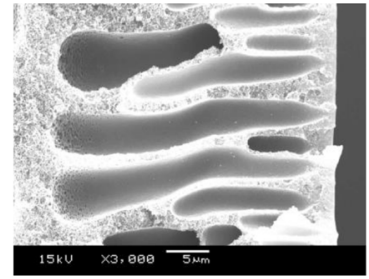

(SEM). 
inside (PDI) flow. The filtration profile of the albumin protein solution using UF0 and UFT304 membranes at various operational pressures is shown in Figure $2 \mathrm{a}$ (underlying data ${ }^{13}$ ). The flux of UFT304 membrane at the beginning of this experiment with an operating pressure of 0.3 atm was $63.60 \mathrm{~L} / \mathrm{m}^{2} . \mathrm{h}$. Flux increased significantly with the increase of the operating pressure which reached $161.00 \mathrm{~L} / \mathrm{m}^{2}$.hour at a pressure of $1.5 \mathrm{~atm}$. The flux of UF0 membrane at the starting point (operating pressure $0.3 \mathrm{~atm}$ ) was much lower, $32.0 \mathrm{~L} / \mathrm{m}^{2} . \mathrm{h}$. At the highest operating pressure $(1.5 \mathrm{~atm})$, the flux of UF0 membrane was about $53.0 \mathrm{~L} / \mathrm{m}^{2} . \mathrm{h}$.

The difference of flux between the two membranes is likely due to the differences in porosity. Tetronic 304 is a polymeric additive which acts as a pore-forming media. This additive is usually called the membrane-modifying agent (MMA). The increase of membrane pore size with blending MMA into the polymer solution is one of the easiest methods to improve membrane performance fabricated by the phase inversion method $^{14}$.
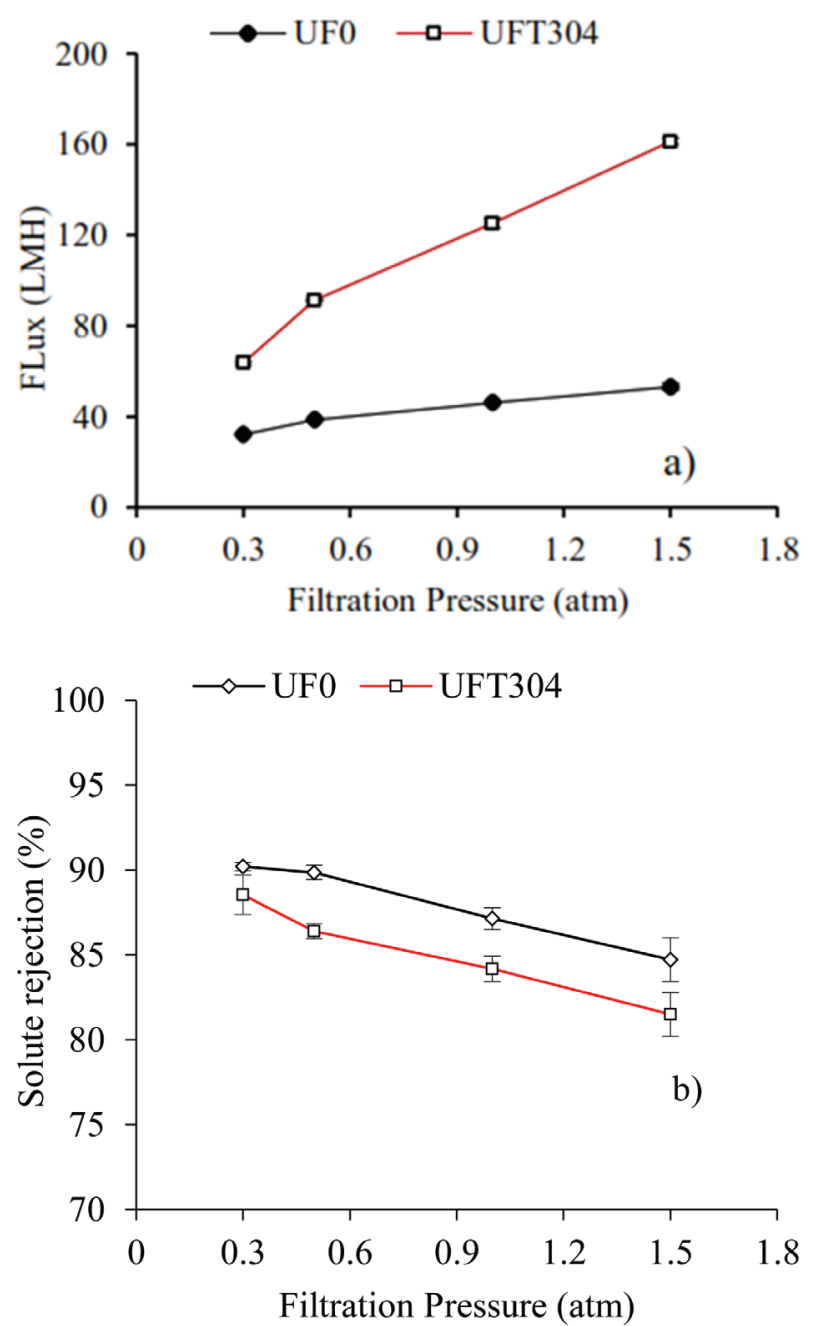

Figure 2. The ultrafiltration performance of membrane in term of flux (a), and solute rejection (b).
The rejection capability of albumin solution of the two membranes is shown in Figure $2 b$ (underlying data $a^{15}$ ). Albumin rejection by UF0 membrane $>90 \%$ was achieved at $0.5 \mathrm{~atm}$. Increasing the operating pressure resulted more albumin particles slipping into the permeate section. For all of the tested operating pressures the rejection of albumin solution by the two membranes remained above $80 \%$.

\section{Filtration stability}

Filtration stability is the capability of a membrane to filter solute per time unit and operating pressure. This test corresponds to the durability of the membrane (lifetime). The result of stability test of the membrane on BSA filtration using UF0 and UFT304 membranes at 0.5 atm are shown in Figure 3 (underlying data ${ }^{16}$ ).

The permeability of the UFT304 membrane at the initial operating pressure of $0.3 \mathrm{~atm}$ was $90.75 \mathrm{~L} / \mathrm{m}^{2}$.h.atm. Meanwhile, the permeability of UF0 membrane at 0.3 atm much lower, $14.38 \mathrm{~L} / \mathrm{m}^{2}$.h.atm. The performance of filtration in these two membrane types was closely related to the morphological structure of the membrane as shown in Figure 1. Compared with the UF0 membrane, the UFT304 membrane had a larger pore structure with a higher porosity. The structure of finger-like macrovoid was also longer, and there was no sponge structure in the middle of membrane section. This difference of pore structure likely resulted in the UFT304 membrane's higher filtration capability.

Along with longer filtration time, the permeability of these two membrane types decreased due to the fouling in membrane pore surface. However, the permeability of UFT304 membrane was still at $5.60 \mathrm{~L} / \mathrm{m}^{2}$.h.atm after 120 minutes of filtration. In contrast the permeability of the UF0 membrane which was almost 0 . The filtration profile of UFT304 membrane is more stable than UF0 membrane. The stability of filtration for UFT304 membrane was closely related to the hydrophilicity

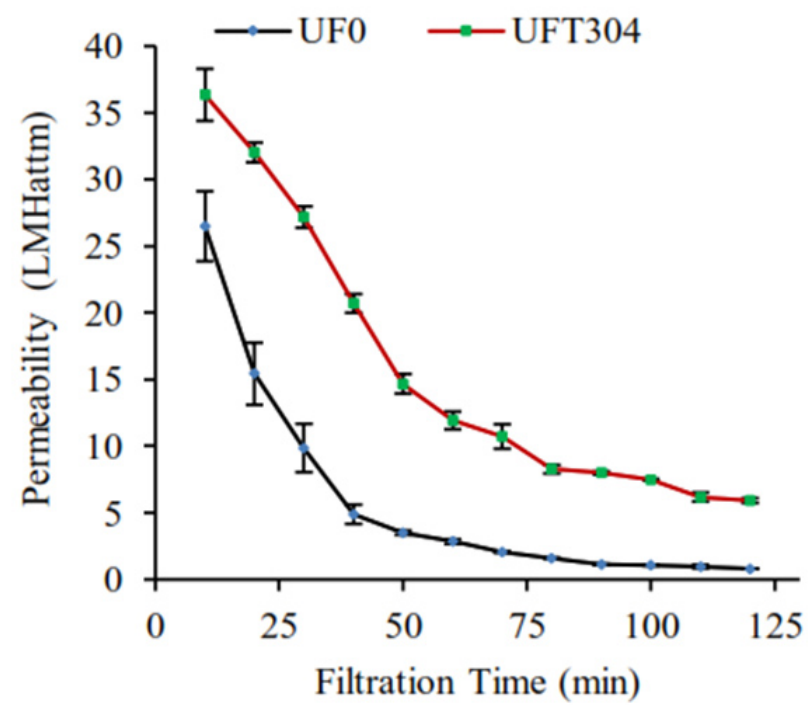

Figure 3. Filtration stability of UF0 and UFT304 membrane. 
property of this membrane. UFT304 membrane was more hydrophilic with water contact angle of $62.0^{\circ}$, compared with UF0 membrane with water contact angle of $74.0^{\circ}$. The hydrophilic membrane has the capability to hold the fouling better than hydrophobic membrane ${ }^{17}$.

The capability to reduce fouling in this hydrophilic membrane is related to the interaction force between membrane surface and solution particle (protein). The content of polyethylene oxide (PEO) chain in the Tetronic additive becomes a block (steric repulsion) for protein molecules, preventing them reaching the membrane surface ${ }^{18}$. Thus, the protein molecule unlikely to attach the membrane surface. Therefore, the fouling process can be minimized.

\section{Conclusion}

The application of ultrafiltration membrane technology to separate albumin protein was conducted with two types of hollow fibre membranes, namely UF0 and UFT304. Based on the results of SEM analysis, UFT304 membrane has more finger shape structures than UF0 membrane. The results of the ultrafiltration test showed that the UFT304 membrane has better performance in terms of the stability of the flux. The rejection of the BSA solution was higher than $80 \%$ for both membranes.

\section{Data availability}

Underlying data

Figshare: Supplementary data 1. https://doi.org/10.6084/m9. figshare.8109335.v $1^{13}$
This project contains the following underlying data:

1. Membrane flux.csv (Raw data for membrane flux underlying Figure 2a)

Figshare: Supplementary data 2. https://doi.org/10.6084/m9. figshare.8109332.v3 ${ }^{15}$

This project contains the following underlying data:

2. Membrane Rejection.csv (Raw data for solute rejection underlying Figure 2b)

Figshare: Supplementary data 3. https://doi.org/10.6084/m9. figshare.8109338.v2 $2^{16}$

This project contains the following underlying data:

3. Water permeability of BSA solution.csv (Raw data for BSA filtration profile underlying Figure 3)

Figshare: SEM images. https://doi.org/10.6084/m9.figshare. 8215862.v2 $2^{12}$

This project contains the following underlying data:

- SEM images.pdf (Raw SEM images)

Data are available under the terms of the Creative Commons Attribution 4.0 International license (CC-BY 4.0).

Acknowledgement

We express our gratitude to Indonesia's Ministry of Research, Technology and Higher Education for funding research grant of "Basic Research" scheme of 2019 (70/UNII.2/SP3/2019)
1. Tini M, Jewell UR, Camenisch G, et al:: Generation and application of chicken egg yolk antibodies. Comp Biochem Physiol A Mol Integr Physiol. 2002; 131(3): 569-74. PubMed Abstract | Publisher Full Text

2. Shaper AG, Wannamethee SG, Whincup PH: Serum albumin and risk of stroke, coronary heart disease, and mortality: the role of cigarette smoking. J Clin Epidemiol. 2004; 57(2): 195-202. PubMed Abstract | Publisher Full Text

3. Datta D, Bhattacharjee $S$, Nath $A$, et al:: Separation of ovalbumin from chicken egg white using two-stage ultrafiltration technique. Sep Purif Technol. 2009; 66(2): 353-61.

Publisher Full Text

4. Jana S, Purkait MK, Mohanty K: Clay supported polyvinyl acetate coated composite membrane by modified dip coating method: Application for the purification of lysozyme from chicken egg white. J Memb Sci. 2011; 382(1-2): 243-51. Publisher Full Text

5. Emin C, Kurnia E, Katalia I, et al: Polyarylsulfone-based blend ultrafiltration membranes with combined size and charge selectivity for protein separation. Sep Purification Technol. 2018; 193: 127-38.

Publisher Full Text

6. Ishak NF, Hashim NA, Monash P, et al:: Recent progress in the hydrophilic modification of alumina membranes for protein separation and purification. Ceram Int. 2017; 43(1 Part B): 915-25.

Publisher Full Text

7. Mayani M, Filipe CDM, Ghosh R: Cascade ultrafiltration systems - Integrated processes for purification and concentration of lysozyme. J Memb Sci. 2010; 347(1-2): 150-8.

Publisher Full Text

8. Arahman N, Mulyati S, Lubis MR, et al:: Modification of polyethersulfone hollow fiber membrane with different polymeric additives. Membr Water Treat. 2016; 7(4): 355-65. Publisher Full Text
9. Arahman N, Maimun T, Bilad MR: Fabrication of Polyethersulfone Membranes Using Nanocarbon as Additive. Int J Geomate. 2018; 15(50): 51-57. Publisher Full Text

10. Arahman N, Satria S, Razi F: The Effect of $\mathrm{Ca}$ and $\mathrm{Mg}$ lons on the Filtration Profile of Sodium Alginate Solution in a Polyethersulfone-2-(methacryloyloxy) Ethyl Phosphorylchloline Membrane. Water. 2018; 10(9): 1207. Publisher Full Text

11. Lv C, Su Y, Wang Y, et al.: Enhanced permeation performance of cellulose acetate ultrafiltration membrane by incorporation of Pluronic F127. J Memb Sci. 2007; 294(1-2): 68-74 Publisher Full Text

12. Arahman N, Razi F, mulyati S: SEM images. figshare. Figure. 2019. http://www.doi.org/10.6084/m9.figshare.8215862.v2

13. Arahman N, Razi F, mulyati S: Supplementary data 1. figshare. Dataset. 2019 http://www.doi.org/10.6084/m9.figshare.8109335.v1

14. Loh $\mathrm{CH}$, Wang $\mathrm{R}$, Shi $\mathrm{L}$, et al:: Fabrication of high performance polyethersulfone UF hollow fiber membranes using amphiphilic Pluronic block copolymers as pore-forming additives. J Memb Sci. 2011; 380(1-2): 114-23. Publisher Full Text

15. Arahman N, Razi F, Mulyati S: Supplementary data 2. figshare. Dataset. 2019 http://www.doi.org/10.6084/m9.figshare.8109332.v3

16. Arahman N, Razi F, Mulyati S: Supplementary data 3. figshare. Dataset. 2019. http://www.doi.org/10.6084/m9.figshare.8109338.v2

17. Wang $Y Q$, Su YL, Ma XL, et al:: Pluronic polymers and polyethersulfone blend membranes with improved fouling-resistant ability and ultrafiltration performance. J Memb Sci. 2006; 283(1-2): 440-7. Publisher Full Text

18. Jeon SI, Andrade JD: Protein-surface interactions in the presence of polyethylene oxide: II. Effect of protein size. J Colloid Interface Sci. 1991; 142(1): 159-66. Publisher Full Text 


\title{
Open Peer Review
}

\section{Current Peer Review Status:}

\section{Version 2}

Reviewer Report 20 November 2019

https://doi.org/10.5256/f1000research.23358.r56299

(C) 2019 Marbelia L. This is an open access peer review report distributed under the terms of the Creative Commons Attribution License, which permits unrestricted use, distribution, and reproduction in any medium, provided the original work is properly cited.

Lisendra Marbelia

Department of Chemical Engineering, Gadjah Mada University, Yogyakarta, Indonesia

Competing Interests: No competing interests were disclosed.

I confirm that I have read this submission and believe that I have an appropriate level of expertise to confirm that it is of an acceptable scientific standard.

Reviewer Report 18 November 2019

https://doi.org/10.5256/f1000research.23358.r56298

(C) 2019 Nagendran A. This is an open access peer review report distributed under the terms of the Creative Commons Attribution License, which permits unrestricted use, distribution, and reproduction in any medium, provided the original work is properly cited.

\author{
Alagumalai Nagendran \\ Polymeric Materials Research Lab, PG \& Research Department of Chemistry, Alagappa \\ Government Arts College, Karaikudi, India \\ Author responded to my comments. \\ Competing Interests: No competing interests were disclosed. \\ I confirm that I have read this submission and believe that I have an appropriate level of \\ expertise to confirm that it is of an acceptable scientific standard.
}

\section{Version 1}


Reviewer Report 01 November 2019

https://doi.org/10.5256/f1000research.20527.r54407

(C) 2019 Nagendran A. This is an open access peer review report distributed under the terms of the Creative Commons Attribution License, which permits unrestricted use, distribution, and reproduction in any medium, provided the original work is properly cited.

\section{Alagumalai Nagendran}

Polymeric Materials Research Lab, PG \& Research Department of Chemistry, Alagappa

Government Arts College, Karaikudi, India

F Razi et al. reported the performance of BSA filtration by PES-Tetronic 304 UF membranes. Authors have reported enough characterization and comprehensive discussion. It may be indexed and authors should consider the following issues:

1. Commercial membranes used made it less attractive. If we synthesize, it can optimize the performance characteristics much better. For example: BSA Rejection reported in this study is $80 \%$. If we fabricate, still higher rejection can be achieved

2. The role of Tetronic 304 in the modified membrane may be clearly explained in discussion section. Is it ok for long term operation?

Is the work clearly and accurately presented and does it cite the current literature? Yes

Is the study design appropriate and is the work technically sound?

Yes

Are sufficient details of methods and analysis provided to allow replication by others? Yes

If applicable, is the statistical analysis and its interpretation appropriate? Yes

Are all the source data underlying the results available to ensure full reproducibility? Yes

Are the conclusions drawn adequately supported by the results?

Yes

Competing Interests: No competing interests were disclosed.

Reviewer Expertise: Ultrafiltration Membranes, Proton Exchange Membranes

I confirm that I have read this submission and believe that I have an appropriate level of expertise to confirm that it is of an acceptable scientific standard, however I have 


\section{significant reservations, as outlined above.}

Author Response 02 Nov 2019

Nasrul Arahman, Syiah Kuala University, Banda Aceh, Indonesia

1. Commercial membranes used made it less attractive. If we synthesize, it can optimize the performance characteristics much better. For example: BSA Rejection reported in this study is $80 \%$. If we fabricate, still higher rejection can be achieved

Response: Thank You. The statement raised by the reviewer is correct that the synthesized membrane can optimize the characteristic of membrane and its performance on filtration

1. The role of Tetronic 304 in the modified membrane may be clearly explained in discussion section. Is it ok for long term operation?

Response: thank you for the valuable comments. In this study we examined for 2 hours filtration. More examination for long term operation is planned in our future study.

Competing Interests: We declare that there is no competing interest

Reviewer Report 06 August 2019

https://doi.org/10.5256/f1000research.20527.r51291

(c) 2019 Marbelia L. This is an open access peer review report distributed under the terms of the Creative Commons Attribution License, which permits unrestricted use, distribution, and reproduction in any medium, provided the original work is properly cited.

\section{Lisendra Marbelia}

Department of Chemical Engineering, Gadjah Mada University, Yogyakarta, Indonesia

This article tries to compare the performance of two membranes type for BSA filtration. The two membranes are PES based membranes, UF0 and UFT304. Both membranes are PES/NMP based membranes, in which UFT304 is modified with Tetronic 304.

From the characterization in this study, it was seen that UFT304 is more hydrophilic (lower contact angle) and also more porous (fingerlike structure in SEM). Because of these properties, filtration results showed that UFT 304 has higher flux (fig 2.a) and also more sustained (fig 3) for a longer BSA filtration test, but with a slightly lower solute rejection (fig 2.b).

These above-mentioned finding and conclusions are obtained, shown and well explained in this article.

Some suggestions and revision which should be applied to improve the quality of the paper are as follows:

1. In the abstract, results part...It is written that UFT304 is better since it has higher flux. But for the rejection it is only mentioned for the UFO membranes. Better mention for the 
UFT304.

2. In the introduction, last paragraph about the Tetronic modified PES membranes... please add reference here.

3. In the method, more detailed information should be added on how the data were recorded. First, for the filtration with several pressure, how long was the filtration? Is it 10 minutes? Please write it accordingly. Also, related to the filtration experiments, it is not mentioned about the replications (in supplementary, it is shown that there are data replications). The authors should add this information in the methodology. How many replications and how the average data was calculated. Furthermore, the authors should add error bar to the graphs (2a, 2b and 3).

4. In the result, when discussing flux and rejection of BSA, it is written that the differences between the two membranes is due to differences in pore size. The authors should differentiate between pore size and porosity. Also in the discussion, it is mentioned pore density...It would be more appropriate to refer to this as porosity (finger like structure seen on SEM), otherwise it might be confused with pore size and density on the surface which are not observed in this study.

Typos:

Introduction, last paragraph - NMP instead of MNP

Method, first paragraph - N-Methyl-2-pyrrolidone instead of N-metilpirrolidon

Is the work clearly and accurately presented and does it cite the current literature? Yes

Is the study design appropriate and is the work technically sound? Yes

Are sufficient details of methods and analysis provided to allow replication by others? Partly

If applicable, is the statistical analysis and its interpretation appropriate? Not applicable

Are all the source data underlying the results available to ensure full reproducibility? Yes

Are the conclusions drawn adequately supported by the results? Yes

Competing Interests: No competing interests were disclosed.

Reviewer Expertise: Membrane Technology, Wastewater Treatment, Bioprocess Engineering

I confirm that I have read this submission and believe that I have an appropriate level of expertise to confirm that it is of an acceptable scientific standard, however I have significant reservations, as outlined above. 
Author Response 02 Nov 2019

Nasrul Arahman, Syiah Kuala University, Banda Aceh, Indonesia

\section{Comment 1}

In the abstract, results part...It is written that UFT304 is better since it has higher flux. But for the rejection it is only mentioned for the UFO membranes. Better mention for the UFT304.

Response

Thank You for comments. We revise the sentence as follow: Solute rejection reaches 90 and $88 \%$ for ultrafiltration of BSA solution on the operating pressure of $0.5 \mathrm{~atm}$ using UF0 and UFT304 membranes, respectively

\section{Comment 2.}

In the introduction, last paragraph about the Tetronic modified PES membranes... please add reference here.

\section{Response}

Thank You for your suggestion. We putted a reference in last paragraph of introduction about the Tetronic modified PES membranes

Comment 3.

In the method, more detailed information should be added on how the data were recorded. first for the filtration with several pressure, how long was the filtration? Is it 10 minutes? Please write it accordingly. Also, related to the filtration experiments, it is not mentioned about the replications (in supplementary, it is shown that there are data replications). The authors should add this information in the methodology. How many replications and how the average data was calculated. Furthermore, the authors should add error bar to the graphs (2a, $2 b$ and 3$)$.

Response: Thank You for reviewer suggestion. We have added the information in methods part. We have revised the graphs in Fig. $(2 a, 2 b, 3)$ by including error bar.

Comment 4.

In the result, when discussing flux and rejection of BSA, it is written that the differences between the two membranes is due to differences in pore size.

The authors should differentiate between pore size and porosity. Also in the discussion, it is mentioned pore density.

It would be more appropriate to refer to this as porosity (finger like structure seen on SEM), otherwise it might be confused with pore size and density on the surface which are not observed in this study.

Response: The point raised by the reviewer is correct. We have revised our explanation as porosity.

Comment 5.

Typos:

Introduction, last paragraph - NMP instead of MNP 
Method, first paragraph - N-Methyl-2-pyrrolidone instead of N-metilpirrolidon Response: Thank You for the correction. We have revised the typo

Competing Interests: We declare that there is no competing interest

The benefits of publishing with F1000Research:

- Your article is published within days, with no editorial bias

- You can publish traditional articles, null/negative results, case reports, data notes and more

- The peer review process is transparent and collaborative

- Your article is indexed in PubMed after passing peer review

- Dedicated customer support at every stage

For pre-submission enquiries, contact research@f1000.com 